\title{
List of plates
}

1 Albert Rémy as Chico in Tirez sur le pianiste,

Films du Carrosse, 1960

page 109

2 Jean-Pierre Léaud as Antoine Doinel in Les 400 coups. Films du Carrosse, 1959

3 Catherine Deneuve as Marion and Jean-Paul Belmondo as Louis in La Sirène du Mississippi, Films du Carrosse/MGM, 1969

4 Jean-Pierre Léaud as Antoine Doinel in Baisers volés. Films du Carrosse, 1968

5 Jeanne Moreau as Julie Kohler in La Mariée était en noir. Films du Carrosse/MGM, 1967

6 Caroline Sihol as Marie-Christine Vercel and Jean-Louis Trintignant as Julien Vercel in Vivement dimanche!. Films du Carrosse, 1982

7, 8 François Trufraut as Dr Itard and Jean-Pierre Cargol as Victor in L'Enfant sauvage, Films du Carrosse/MGM, 1970

9 Jacqueline Bisset as Julie Baker, Nike Arrighi as Odile and David Markham as Dr Nelson in La Nuit américaine, Films du Carrosse/Warner, 1973 All stills courtesy of BFI Stills, Posters and Designs 